\title{
The influence of cell dimensions on the vulnerability of ventricular myocytes to lethal injury by high-intensity electrical fields
}

\author{
Jair Trapé Goulart, Pedro Xavier de Oliveira, José Wilson Magalhães Bassani, Rosana Almada Bassani*
}

\begin{abstract}
Application of high intensity electric fields (HIEF) to the myocardium is commonly used for cardiac defibrillation/cardioversion. Although effective at reversing life-threatening arrhythmias, HIEF may cause myocyte damage due to membrane electropermeabilization. In this study, the influence of cell length and width on HIEF-induced lethal injury was analyzed in isolated rat cardiomyocytes in parallel alignment with the field. The field-induced maximum variation of membrane potential $\left(\Delta \mathrm{V}_{\max }\right)$ was estimated with the Klee-Plonsey model. The studied myocyte population was arranged in two group pairs for comparison: the longest vs. the shortest cells, and the widest vs. narrowest cells. Threshold field intensity was significantly lower in the longest vs. shortest myocytes, whereas cell width influence was not significant. The threshold $\Delta \mathrm{V}_{\max }$ was comparable in all groups. Likewise, a significant leftward shift of the lethality curve (i.e., relationship of the probability of lethality vs. field intensity) of the longest cells was observed, evidencing greater sensitivity to HIEF-induced damage. However, the lethality curve as a function of $\Delta \mathrm{V}_{\max }$ was similar in all groups, confirming a prediction of the Klee-Plonsey model. The similar results for excitation and injury at threshold and HIEF stimulation, respectively, indicate that: a) the effect of cell length on the sensitivity to the field would be attributable to differences in field-induced membrane polarization that lead to excitation or lethal electroporation; b) the Klee-Plonsey model seems to be reliable for analysis of cell interaction with $\mathrm{HIEF}$; c) it is possible that increased cell length in hypertrophied hearts enhances myocyte fragility upon defibrillation/cardioversion.
\end{abstract}

Keywords Electric field, Cardiac myocytes, Lethal cell injury, Modeling, Defibrillation.

\section{Influência das dimensões celulares sobre a vulnerabilidade de miócitos ventriculares ao efeito letal de campos elétricos de alta intensidade}

Resumo Campos elétricos de alta intensidade (HIEF) são aplicados ao miocárdio durante desfibrilação e cardioversão. Embora eficazes na reversão de arritmias potencialmente letais, HIEF podem lesar cardiomiócitos por eletropermeabilização da membrana. Neste estudo, a influência das dimensões celulares sobre o efeito letal de HIEF foi estudada em cardiomiócitos isolados de rato alinhados paralelamente ao campo. A máxima variação do potencial de membrana induzida pelo campo $\left(\Delta V_{\max }\right)$ foi calculada com o modelo de Klee-Plonsey. As células estudadas foram distribuidas em dois pares de grupos de acordo com seu comprimento e largura. A intensidade limiar do campo não dependeu da largura celular, mas sim do comprimento (menor nas células mais longas, $p<0.001)$, enquanto $\Delta V_{\max }$ no limiar foi comparável entre os grupos. Nas células mais longas, observou-se desvio à esquerda $(p<0.01)$ da curva que descreve a relação entre probabilidade de letalidade e a intensidade do campo, evidenciando maior sensibilidade à ação deletéria de HIEF. Porém, a curva de letalidade em função de $\Delta V_{\max }$ foi semelhante em todos os grupos, o que confirma a predição pelo modelo de Klee-Plonsey. A similaridade de resultados com estimulação limiar e com HIEF indica que: a) o efeito do comprimento celular sobre a sensibilidade ao campo poderia ser atribuído a diferenças no grau de polarização da membrana durante a aplicação do estímulo; b) o modelo de Klee-Plonsey parece ser confiável para a análise da interação espacial da célula com HIEF; c) é possível que o maior comprimento celular em miócitos hipertrofiados os torne mais susceptiveis a lesão durante desfibrilação/cardioversão.

Palavras-chave Campo elétrico, Miócitos cardíacos, Lesão celular letal, Modelamento, Desfibrilação. 


\section{Introduction}

Several pathophysiological conditions may be associated with disturbances in heart rhythm, which may result in impairment of cardiac pumping function. Ventricular fibrillation is considered the most severe of the arrhythmia types, as it frequently leads to sudden cardiac death. The latter, with estimated incidence of $0.1-0.2 \%$ of the adult population per year in Western industrialized countries, represents $\sim 50 \%$ of the deaths related to coronary disease (Zipes et al., 2006).

Electrical defibrillation, namely the application of high intensity electric fields (HIEF) to the heart, is the most commonly used and most effective procedure to reverse ventricular fibrillation in the emergency setting (Zipes et al., 2006). As a rule, it is considered that the likelihood of success of defibrillation keeps a positive relationship with shock strength, but only up to a certain point: increasing shock intensity above the optimal range diminishes success rate (Dosdall et al., 2010; Fotuhi et al., 1999). While poor underlying myocardial conditions may be partially accountable for the therapeutic failure of very strong shocks, HIEF itself may exert deleterious effects on the heart. Such effects include sustained membrane depolarization, cell damage and conduction block that may facilitate post-shock arrhythmia reinitiation (e.g., Dosdall et al., 2010; Fedorov et al., 2008; Fotuhi et al., 1999; Knisley and Grant, 1985; Oliveira et al., 2008; Sowell and Fast, 2012; Yabe et al., 1990).

The deleterious effects of HIEF are attributable to membrane electropermeabilization (electroporation), i.e., the opening of hydrophilic pores, due to transition of the membrane phospholipid organization brought about by the energy delivered by shock (Weaver and Chizmadzhev, 1996). The electroporated membrane loses its selective permeability, so that large transmembrane flux of ions (including cytotoxic calcium ions) and water, as well as loss of intracellular components, may ensue. When exposed to very strong shocks, the cardiac myocyte develops irreversible hypercontracture, calcium overload and electrical refractoriness, and loses its physical integrity (lethal injury; Knisley and Grant, 1985; Oliveira et al., 2005, 2008).

External field application generates a spatially-varying electrical potential gradient in the extracellular medium that drives the rearrangement of charges on the membrane surfaces, which results in change in the transmembrane electrical potential $\left(\mathrm{V}_{\mathrm{m}}\right)$. Experimental studies indicate that the occurrence of electroporation is highly dependent on the variation of membrane potential $\left(\Delta \mathrm{V}_{\mathrm{m}}\right)$ that results from the field application, and will take place when $\mathrm{V}_{\mathrm{m}}$ exceeds a critical value (Fedorov et al., 2008; O'Neill and Tung, 1991).
Mathematical models have been valuable tools to simulate and predict membrane polarization and electroporation in response to external fields (e.g., Krassowska and Filev, 2007; Valič et al., 2003). However, most of them cannot give much information on $\mathrm{V}_{\mathrm{m}}$. In our laboratory, we have employed the model described by Klee and Plonsey (1976) (K-P model), which allows the estimation of the maximal $\Delta \mathrm{V}_{\mathrm{m}}$ $\left(\Delta \mathrm{V}_{\max }\right)$ upon imposition of an external field. While this model produces consistent results for threshold field stimulation (Bassani et al., 2006; Gomes et al., 2001; Oliveira et al., 2008), it has not been ascertained yet if it also applies for HIEF.

According to the K-P model, the only factors that directly determine $\Delta \mathrm{V}_{\max }$, in addition to the field intensity, are the cell dimensions and field orientation with respect to the cell. In our experimental setting, field-induced extensive electroporation can be indicated by cell lethal injury (Oliveira et al., 2008). Assuming that the critical $\Delta \mathrm{V}_{\text {max }}$ for this effect is similar for a particular cell type (i.e., rat ventricular myocytes) under a given set of experimental conditions, a simple way to test whether the K-P model is applicable to HIEF is to investigate whether $\Delta \mathrm{V}_{\text {max }}$ behaves as predicted when varying a field-independent parameter.

The objective of the present study was to evaluate the influence of cell dimensions (length and width) on the sensitivity of isolated rat ventricular myocytes to the lethal effect of external HIEF, as well as to the estimated $\Delta \mathrm{V}_{\text {max }}$ developed in response to the latter. In addition to providing a test of the usefulness of the K-P model for field intensities close to the range of those attained during defibrillation, this study also addresses a point of potential clinical importance, as cardiomyocyte hypertrophy is commonly associated with conditions that increases the probability of cardiac fibrillation and sudden death occurrence (e.g., Bender et al., 2012; Brouwer et al., 2011; Reinier et al., 2011).

\section{Materials and Methods}

\section{Rat cardiomyocyte preparation}

Myocytes were isolated from the left ventricle of adult (4-6 month-old) male Wistar rats, not previously submitted to any type of experimental manipulation. Myocyte isolation was carried out by coronary perfusion with collagenase I, as described by Penna and Bassani (2010). Cells were used within 12 hours after isolation. The protocols for animal care and use were approved by the institutional Committee of Ethics in Animal Use (CEUA/IB/UNICAMP, protocol 2088-1). 
The cell suspension was plated on a perfusion chamber, of which the bottom was a glass coverslip treated with collagen to enhance cell adhesion. A pair of wire platinum electrodes was inserted into slits along the chamber lateral inner walls, spanning most of the length of the chamber. The chamber was placed on a microscopy system (Ricardo et al., 2006), and cells were perfused $(\sim 3 \mathrm{~mL} / \mathrm{min})$ with modified Tyrode's solution (mM composition: $140 \mathrm{NaCl}$; $6 \mathrm{KCl} ; 1.5 \mathrm{MgCl}_{2} .6 \mathrm{H}_{2} \mathrm{O} ; 1 \mathrm{CaCl}_{2} .2 \mathrm{H}_{2} \mathrm{O} ; 10$ HEPES; 11.1 glucose; $\mathrm{pH} 7.4$ ) at $23^{\circ} \mathrm{C}$. Vacuum suction of the solution at the chamber outlet ensured that the height of the solution column in the chamber (thus, solution volume and conductivity) could be kept constant. Perfusion was interrupted during measurement of stimulus amplitude.

By means of a CCD camera, the cell image was projected on a video monitor, and captured (mod. Dazzle Digital VideoCreator 150, Pinnacle Systems, North Canton, USA) for data storage and offline analysis. Cell length and width, i.e., major and minor axes ( $2 \mathrm{c}$ and $2 \mathrm{a}$, respectively), were measured on the screen using a graduated scale $(<1 \mu \mathrm{m}$ resolution) that was calibrated with aid of a graticule $(10 \mu \mathrm{m}$ resolution, Carl Zeiss, Göttingen, Germany) projected on the screen (estimated error $<3 \%$ ).

Only cells that met the following requirements were selected for this study: a) presence of clear striations, as well as preserved structure and contractile function; b) parallel orientation of the cell major axis to the field direction, which was necessary to isolate cell dimension and field intensity as the only factors determining $\Delta \mathrm{V}_{\text {max }}$; and c) location at least at $2 \mathrm{~mm}$ from the electrodes, which is required for low error $(<2 \%)$ in field estimation (Oliveira et al., 2008).

\section{Field and $\Delta V_{\max }$ estimation}

The field intensity $(\mathrm{V} / \mathrm{cm})$ was calculated as in the case of a parallel plate capacitor (Gomes et al., 2001), as the ratio of the stimulus voltage and the distance between the electrodes $(0.75 \mathrm{~cm})$.

For both threshold and HIEF stimulation, $\Delta \mathrm{V}_{\max }$ was estimated as in Equation 1 (Klee and Plonsey, 1976), assuming for the myocyte a prolate spheroidal geometry, and that the membrane could be represented by dielectric shell (Bassani et al., 2006; Gomes et al., 2001; Oliveira et al., 2008):

$$
\Delta \mathrm{V}_{\max }(\mathrm{E}, \theta, \mathrm{a}, \mathrm{c})=\mathrm{E}\left(\mathrm{a}^{2} \mathrm{~A}^{2} \sin ^{2} \theta+\mathrm{c}^{2} \mathrm{C}^{2} \cos ^{2} \theta\right)^{1 / 2}
$$

where $\mathrm{E}$ is the field intensity; $a$ and $c$ are half the length of cell minor and major axes, respectively; A and $\mathrm{C}$ are geometrical parameters (described below); and $\theta$ is the angle between the field lines and the cell major axis.

$$
\begin{aligned}
& A=\left\{1-0.5 \varepsilon^{-2}-\left[0.25\left(1-\varepsilon^{2}\right) \cdot \ln (1-\varepsilon) /(1+\varepsilon)\right] \varepsilon^{-3}\right\}^{-1} \\
& C=\left\{\varepsilon^{-2}-\left[0.5\left(1-\varepsilon^{2}\right) \cdot \ln (1-\varepsilon) /(1+\varepsilon)\right] \varepsilon^{-3}\right\}^{-1} \\
& \varepsilon=\left(1-a^{2} / c^{2}\right)^{1 / 2}
\end{aligned}
$$

As $\theta$ was null due to the parallel cell orientation, the equation could be simplified to:

$\Delta V_{\max }=E c C$

\section{Experimental protocol}

Only one cell was studied for each cell suspension sample plated on the chamber. Initially, the stimulation threshold for each cell was determined as follows. Cells were subjected to suprathreshold stimulation at $0.5 \mathrm{~Hz}$ with biphasic voltage pulses $(10 \mathrm{~ms}$ total duration), and then stimulus amplitude was gradually decreased until stimulation failed to elicit a twitch. The threshold stimulus amplitude, defined as the least stimulus voltage that evoked contractile response (Gomes et al., 2001), was used for estimation of the threshold stimulation field.

Cyclic stimulation $(0.5 \mathrm{~Hz}, 1.2$ times the threshold amplitude) continued for 30 seconds. Two seconds after the last near-threshold stimulus, a high power stimulator (mod S48K, Grass, West Warwick, USA) delivered a single test stimulus (HIEF stimulation; 10 ms-long, monophasic pulse). The test stimulus amplitude was a factor (from 8 to 30 ) of the threshold. The first test amplitude used was the lowest, i.e., 8 -fold the threshold voltage. The cell then was rested for a variable period, until it was fully recovered from the shock (i.e., it recovered quiescence and full responsiveness to near-threshold stimulation). The protocol was repeated, increasing the amplitude of the test pulse until the production of lethal injury. The latter was identified by sustained hypercontracture accompanied by irreversible loss of responsiveness to electrical stimulation and of discernible cellular structure (Oliveira et al., 2008).

\section{Experimental groups and statistical analysis}

Twenty three cells were used in this study, which were arranged in 2 pairs of groups: the cells with the greatest and lowest $2 \mathrm{c}$ values formed the long and short groups, respectively (10 cells in each group), whereas the cells with the greatest and lowest 2a values constituted the wide and narrow groups, respectively ( $\mathrm{N}=10$ per group). This means that most cells of the total population belonged to two groups (e.g., short 
and wide). The threshold values of electric field and $\Delta \mathrm{V}_{\max }$, as well as cell dimensions ( $2 \mathrm{c}$ and $2 \mathrm{a}$ ), were compared within each group pair with Student's t test for unpaired samples.

For each group, the maximum non-lethal and the minimum lethal field intensities (or the corresponding $\Delta \mathrm{V}_{\max }$ values) determined in each cell were used as the primary data for the survival analysis (Kleinbaum, 1996), which generates a table of the probability of lethality as a function of field intensity or $\Delta \mathrm{V}_{\max }$. These lethality curves were compared within each group pair with the Mantel-Cox test (Mantel, 1966). For all statistical comparisons, $\mathrm{p}<0.05$ was considered as indicative of statistically significant difference.

To describe the lethality curves and to provide a mean parameter of sensitivity to the field or $\Delta \mathrm{V}_{\max }$, the data from the probability tables were fitted with a monoexponential function:

$$
P=\frac{1}{1+(L 50 / X)^{n}}
$$

where $\mathrm{P}$ is the probability of lethality, $\mathrm{X}$ is the field intensity or $\Delta \mathrm{V}_{\max }$; $\mathrm{L} 50$ is the $\mathrm{X}$ value for $\mathrm{P}=0.5$; and $n$ is the Hill coefficient. In all non-linear regressions, $\mathrm{R}^{2}$ was greater than 0.95 .

Values are presented as means \pm standard error. All analyses were performed with Prism 5.03 (GraphPad Software, Inc, San Diego, USA).

\section{Results}

\section{Threshold stimulation}

As shown in Table 1, it was possible to arrange the original cell population in group pairs with different dimensions. Significant difference between the long and short groups was detected for $2 \mathrm{c}(\mathrm{p}<0.001)$, but not for $2 \mathrm{a}(\mathrm{p}>0.63)$, whereas the opposite occurred for the comparison between wide and narrow groups $(\mathrm{p}<0.001$ for $2 \mathrm{a} ; \mathrm{p}>0.78$ for $2 \mathrm{c})$.

The threshold field was $\sim 25 \%$ lower in the long group, compared to the short group $(\mathrm{p}=0.001)$.
However, the threshold $\Delta \mathrm{V}_{\max }$ values were comparable in these groups $(p>0.74)$. On the other hand, neither the field nor $\Delta \mathrm{V}_{\text {max }}$ at threshold was significantly different between wide and narrow groups $(\mathrm{p}>0.08)$.

\section{HIEF stimulation}

Cell death occurred in the range of field values typically found during cardiac defibrillation (up to $190 \mathrm{~V} / \mathrm{cm}$; Yabe et al., 1990).

As it happened for threshold stimulation, statistically significant difference was observed in the response of the long and short groups to HIEF $(\mathrm{p}<0.003$; Mantel-Cox test). This difference was characterized by a marked leftward shift in the lethality curve of the former group, which indicated that lower field amplitude was required to produce lethal injury in longer cells (Figure 1). For instance, the mean field intensity estimated to cause death in $50 \%$ of the cells was $20 \%$ lower in the long group than that in the short group (Table 2). However, a comparable relationship between the probability of lethal damage and field intensity was observed in the wide and narrow groups ( $\mathrm{p}>0.35$; Figure 1; Table 2).

Regarding the influence of cell dimensions on the probability of lethality as a function of $\Delta \mathrm{V}_{\max }$, no significant differences were observed for the long $\times$ short and the wide $\times$ narrow comparison pairs ( $>0.14$; Figure 2), which indicates that the sensitivity to membrane polarization was not affected by cell dimensions, as expected. The variation of the mean L50 values among groups (Table 2) did not reach 10\%.

\section{Discussion}

The present study shows that myocyte length is an important determinant of the cell sensitivity to externally applied electric field, not only for threshold excitation, but also for lethal injury brought about by HIEF stimulation. This is to our knowledge the first time that the influence of cardiomyocyte dimension has been demonstrated for the field range that may be reached during electrical defibrillation of the heart.

Table 1. Cell dimensions and threshold variables in isolated rat ventricular myocytes. Means \pm standard error values of cell length (2c), cell width (2a), threshold electric field $\left(\mathrm{E}_{\mathrm{T}}\right)$ and estimated maximum variation in transmembrane electrical potential at threshold $\left(\Delta \mathrm{V}_{\max -\mathrm{T}}\right)$ are presented for two pairs of groups: one pair included cells with the greatest and lowest 2c values (long and short), and the other, with cells showing the greatest and lowest $2 \mathrm{a}$ values (wide and narrow), in a total population of 23 myocytes. $\mathrm{N}=10$ for each group. ${ }^{*} \mathrm{p}<0.05$ for comparison of the groups within the pair (Student's t test).

\begin{tabular}{ccccc}
\hline & \multicolumn{2}{c}{ Cell length } & \multicolumn{2}{c}{ Cell width } \\
\hline Group & Long & Short & Wide & Narrow \\
\hline $2 \mathrm{c}(\mu \mathrm{m})$ & $128.9 \pm 3.1$ & $100.9 \pm 2.6^{*}$ & $115.4 \pm 5.3$ & $113.4 \pm 5.4$ \\
$2 \mathrm{a}(\mu \mathrm{m})$ & $26.1 \pm 1.3$ & $25.1 \pm 1.7$ & $31.8 \pm 1.4$ & $22.1 \pm 1.7^{*}$ \\
$\mathrm{E}_{\mathrm{T}}(\mathrm{V} / \mathrm{cm})$ & $2.76 \pm 0.16$ & $3.55 \pm 0.12^{*}$ & $3.24 \pm 0.12$ & $3.06 \pm 0.22$ \\
$\Delta \mathrm{V}_{\text {max-T }}(\mathrm{mV})$ & $22.9 \pm 1.4$ & $23.4 \pm 0.6$ & $24.7 \pm 0.9$ & $22.3 \pm 0.9$ \\
\hline
\end{tabular}


Nevertheless, our results indicate that, in both types of stimulation, the field effects are exerted within a narrow range of membrane polarization, which was not significantly affected by the cell dimensions.

It is well accepted that the application of an external field results in the production of electrical potential gradient in the medium that surrounds the outer surface of the membrane. The electrical potential, which is null at the point equidistant to the electrodes and increases with the proximity of the electrodes, leads to space-dependent variation of $\mathrm{V}_{\mathrm{m}}$, which attains its maximum modulus $\left(\Delta \mathrm{V}_{\max }\right)$ at the membrane regions
Cell length

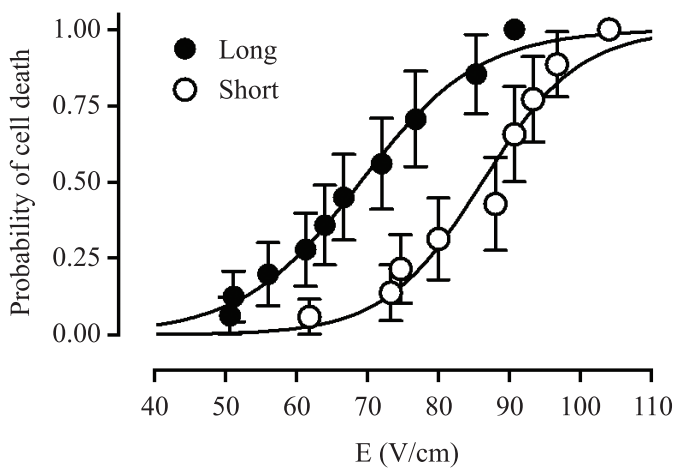

Cell width

(b)

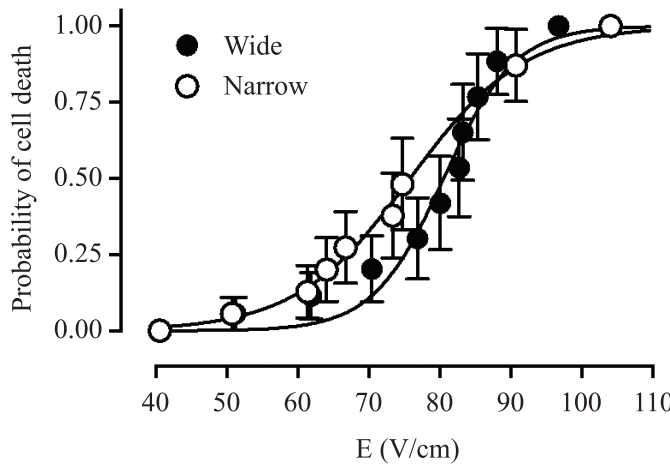

Figure 1. Curves that describe the probability of field-induced lethal injury to isolated rat ventricular myocytes as a function of the field intensity (E), determined in the cell groups formed according to the values of cell length (panel a) and width (panel b). Data are presented as means and respective standard error. The mean parameters of the fitted curves are presented in Table 2. Statistical difference was observed only for the curves shown in panel a $(\mathrm{p}<0.001$; Mantel-Cox test).

Table 2. Mean values of the parameters of the lethality curves in isolated rat ventricular myocytes. The values of field intensity and maximum change in membrane potential $\left(\Delta \mathrm{V}_{\max }\right)$ associated with the probability of death in $50 \%$ of the cell population (L50), as well as the Hill coefficients (n) of the curves, are presented for the pairs of cell groups arranged according to cell length (long and short) and cell width (wide and narrow). The lethality curves for field intensity and $\Delta \mathrm{V}_{\max }$ are presented in Figures 1 and 2, respectively.

\begin{tabular}{ccccc}
\hline & \multicolumn{2}{c}{ Cell length } & \multicolumn{2}{c}{ Cell width } \\
\hline Group & Long & Short & Wide & Narrow \\
\hline Field: $\mathrm{L} 50(\mathrm{~V} / \mathrm{cm})$ & 69.0 & 86.2 & 80.5 & 75.8 \\
$\mathrm{n}$ & 0.052 & 0.064 & 0.087 & 0.054 \\
$\Delta \mathrm{V}_{\max }: \mathrm{L} 50(\mathrm{mV})$ & 585 & 579 & 605 & 550 \\
$\mathrm{n}$ & 0.005 & 0.010 & 0.010 & 0.010 \\
\hline
\end{tabular}

Cell length

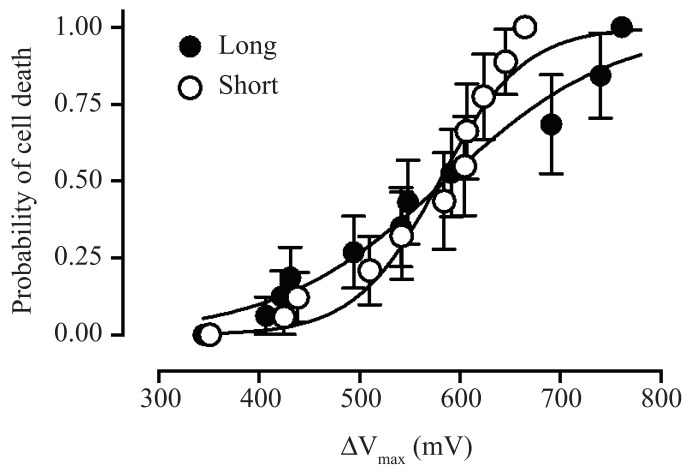

(a)
Cell width

(b)

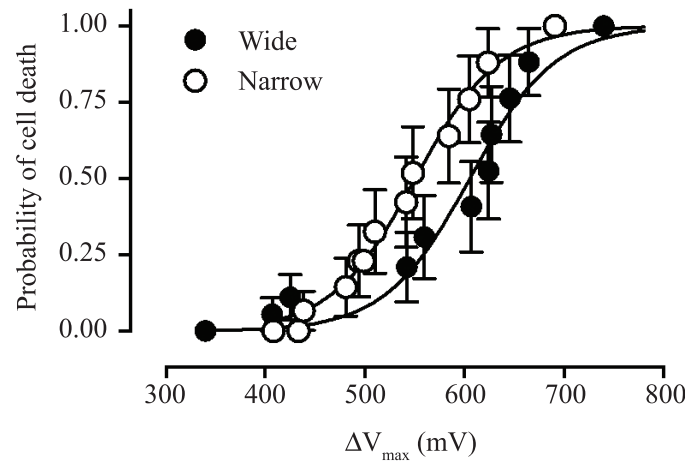

Figure 2. Curves that describe the probability of field-induced lethal injury to isolated rat ventricular myocytes as a function of the estimated maximum variation of membrane potential $\left(\Delta \mathrm{V}_{\max }\right)$, determined in the cell groups formed according to the values of cell length (panel a) and width (panel b). Data are presented as means and respective standard error. The mean parameters of the fitted curves are presented in Table 2. No statistical difference was observed for the curves shown in either panel a or $b(p>0.14$; Mantel-Cox test). 
closest to the electrodes (negative at the anodal end and positive at the cathodal end) (Knisley et al., 1993; Neunlist and Tung, 1997; Sharma and Tung, 2002). If the myocyte major dimension (length) is oriented parallel to the field (i.e., to the imaginary axis between the electrodes), the $\Delta \mathrm{V}_{\max }$ developed at the cell extremities in response to a certain field intensity should be considerably greater than that if the cell orientation is transversal: in the latter case the membrane sites where $\Delta \mathrm{V}_{\mathrm{m}}$ reaches its maximum are much farther from the electrodes. This has been confirmed by both modeling and experimental observations (e.g., Knisley et al., 1993; Oliveira et al., 2008; Sharma and Tung, 2002; Valič et al., 2003), and should result in the need of greater field intensity for $\mathrm{V}_{\mathrm{m}}$ to reach the excitation threshold when orientation is transversal. This was the proposed mechanism to explain why lower field intensity is required for excitation when the orientation of the cell major axis with respect to the external field is parallel (Bassani et al., 2006; Oliveira et al., 2008; Tung et al., 1991).

By the same token, when a field of a given intensity is applied to cells with parallel orientation, however with different lengths, $\Delta \mathrm{V}_{\max }$ should be the greater as the longer is the cell. Our present results are in agreement with this prediction, in that, although $\Delta \mathrm{V}_{\text {max }}$ at threshold was similar in the long and short cell groups, the field intensity required for its attainment was lower for longer cells. Cell width, on the other hand, did not show significant influence on myocyte sensitivity to the field. This was expected, because, for parallel cell orientation, the minor axis of the cell is transversal to the axis between the electrodes. Thus, cell width should not be an important determinant of maximal cell polarization under our experimental conditions (see Equations 1-5).

The presently obtained threshold $\Delta \mathrm{V}_{\mathrm{m}}$ values were close to those determined theoretically and experimentally in rat ventricular myocytes (Bassani et al., 2006; Oliveira et al., 2008; Oshiyama et al., 2012). While the results at threshold level were fully compatible with the K-P model predictions and experimental data, the main question raised was regarding stimulation with HIEF. Although the K-P model was used previously in this condition to examine polarization by HIEF applied at different directions (Oliveira et al., 2008), apparent spacedependent differences in electroporation severity made it difficult to ascertain whether the model was applicable for field-induced cell death.

Differently from threshold excitation, which is a clear-cut phenomenon, electropermeabilization is graded with regard to both extension and pore lifetime, depending on shock parameters, such as intensity and duration (Fedorov et al., 2008; Neunlist and Tung, 1997; Oliveira et al., 2005; Tovar and Tung, 1992). Possibly for this reason, the range of the critical $\mathrm{V}_{\mathrm{m}}$ for permeabilization described for cardiac myocytes and millisecond shock duration is quite wide (250-1000 mV) (e.g., Cheek and Fast, 2004; Neunlist and Tung, 1997; O'Neill and Tung, 1991; Tovar and Tung, 1992). However, in the case of HIEF-induced cell death, it is plausible to conclude that permeabilization should be sufficiently extensive and long-lasting to allow sustained calcium overload and disruption of cell structure. Moreover, it can also be assumed that, under identical experimental conditions, the $\Delta \mathrm{V}_{\max }$ necessary to cause such severe injury should be similar for any rat ventricular cardiomyocyte, no matter its dimensions. Thus, confirmation of the hypothesis that the K-P model was applicable to HIEF-induced cell death required that the influence of cell dimensions on field sensitivity reproduced what had been seen at threshold stimulation, and that $\Delta \mathrm{V}_{\text {max }}$ values were insensitive to cell dimensions. Our results show that these requirements were met: a) significantly lower field intensities (by $\sim 20 \%$ ) were necessary to produce lethal injury in long $v s$. short cells; b) cell width did not exert significant influence on field sensitivity; and c) the estimated $\Delta \mathrm{V}_{\max }$ was fairly similar in all groups (as seen by the absence of significant difference in the lethality curves as a function of $\Delta \mathrm{V}_{\max }$, and the variation below $10 \%$ in the $\Delta \mathrm{V}_{\max }$ values associated with $50 \%$ probability of cell death).

According to our $\Delta \mathrm{V}_{\max }$ values, lethal injury should ensue when $\mathrm{V}_{\mathrm{m}}$ exceeds $-480 \mathrm{mV}$ at the cell anodal extremity (assuming a resting $\mathrm{V}_{\mathrm{m}}$ of $-80 \mathrm{mV}$ ) (Bassani et al., 2004; Oshiyama et al., 2012). Although within the experimentally determined $\mathrm{V}_{\mathrm{m}}$ critical range for electropermeabilization in cardiac myocytes (O’Neill and Tung, 1991), this value is likely to represent an overestimate. It should be stressed that lethal injury must require considerably severe electroporation. Although transient and mild electroporation may occur for $\Delta \mathrm{V}_{\text {max }}$ values below $200 \mathrm{mV}$ (Cheek and Fast, 2004), it does not necessarily lead to cell death, but only to temporary hypoexcitability and spontaneous activity (Oliveira et al., 2005, 2008). Thus, higher membrane polarization should be necessary to induce permeabilization that leads to cell death. In addition, electroporation is a self-limiting phenomenon: the ion fluxes that develop through the electropores curtail membrane polarization due to the field (Cheek and Fast, 2004; Neunlist and Tung, 1997). Because the K-P model does not take into account possible dielectric breakdown of the membrane, the estimated $\Delta \mathrm{V}_{\max }$ should be regarded as the maximum polarization attained had not electroporation interrupted membrane 
charging, and thus is probably higher that the actual values. Nevertheless, the present observation that it was not significantly affected by cell dimensions argues in favor of the usefulness of this model for HIEF application, as long as one is aware of its limitations regarding the absolute values of $\Delta \mathrm{V}_{\max }$.

Finally, the greatest sensitivity to the HIEF deleterious effects in longer cells raises the possibility that hypertrophied myocytes would be more susceptible to lethal injury during defibrillation. Although in the whole heart cells are electrically connected and thus the myocardium should behave as a functional syncytium, a remarkable similarity of the electrical interaction with external field has been observed in isolated myocytes and whole hearts of neonatal rats (Gomes et al., 2001, 2002). Increase in cell length is known to occur in some physiological (pregnancy; Virgen-Ortiz et al., 2009) and pathophysiological conditions, such as mitral insufficiency (Dillon et al., 2012), spontaneous arterial hypertension (R.A. Bassani, unpublished results), dilated cardiomyopathy (Kaistura et al., 1995), and familial hypertrophic cardiomyopathy (Brouwer et al., 2011). Cardiac hypertrophy has been considered an independent factor associated with increased risk of arrhythmia and sudden death (Bender et al., 2012; Reinier et al., 2011), particularly in the case of hypertrophic cardiomyopathy (Brouwer et al., 2011). Although during defibrillation/cardioversion only a fraction of the cardiac myocytes are expected to be in parallel orientation with the field, our results are suggestive that these cells might be at risk of severe injury, which might compromise the success of defibrillation (due to possible conduction block) and recovery of adequate cardiac pumping function. Accordingly, increased defibrillation threshold has been reported in hypertrophic hearts (Almquist et al., 2005; Kalighu et al., 1997; Ott and Reiter, 1997).

\section{Conclusion}

From the present results, it is possible to conclude that the cell major dimension exerts significant influence on the polarization of ventricular myocytes induced by parallel external electrical fields, not only at the excitation threshold, but also at high, defibrillator-type field intensities. As in both cases the results are in agreement with the predictions from the K-P model, it appears that this model is also applicable to the interaction of cells with HIEF. Additionally, the finding of higher sensitivity to HIEF lethal injury associated with greater myocyte length raises the possibility of greater susceptibility to HIEF-induced damage in hypertrophied myocardial cells.

\section{Acknowledgements}

The authors are grateful to the team of the Área de Pesquisa e Desenvolvimento at CEB/UNICAMP for the valuable technical support. This study was funded by CNPq (Proc. 302996/2011-7) and CAPES (scholarship to J.T.G.).

\section{References}

Almquist AK, Montgomery JV, Haas TS, Maron BJ. Cardioverter-defibrillator implantation in high-risk patients with hypertrophic cardiomyopathy. Heart Rhythm. 2005; 2:814-9. PMid:16051115. http://dx.doi. org/10.1016/j.hrthm.2005.05.008

Bassani RA, Altamirano J, Puglisi JL, Bers DM. Action potential duration determines sarcoplasmic reticulum $\mathrm{Ca}^{2+}$ reloading in mammalian ventricular myocytes. Journal of Physiology. 2004; 559:591-607. PMid:15243136 PMCid:1665117. http://dx.doi.org/10.1113/ jphysiol.2004.067959

Bassani RA, Lima KA, Gomes PAP, Oliveira PX, Bassani JWM. Combining stimulus direction and waveform for optimization of threshold stimulation of isolated ventricular myocytes. Physiological Measurement. 2006; 27:851-63. PMid:16868351. http:// dx.doi.org/10.1088/0967-3334/27/9/008

Bender SR, Friedman DJ, Markowitz SM, Lerman BB, Okin PM. Electrocardiographic left ventricular hypertrophy predicts arrhythmia and mortality in patients with ischemic cardiomyopathy. Journal of Interventional Cardiac Electrophysiology. 2012; 34:237-45. PMid:22354775. http://dx.doi.org/10.1007/s10840-011-9661-2

Brouwer WP, Van Dijk SJ, Stienen GMJ, Van Rossum AC, Van der Velden J, Germans T. The development of familial hypertrophic cardiomyopathy: from mutation to bedside. European Journal of Clinical Investigation. 2011; 41:567-78. PMid:21158848. http:// dx.doi.org/10.1111/j.1365-2362.2010.02439.x

Cheek ER, Fast VG. Nonlinear changes of transmembrane potential during electrical shocks: role of membrane electroporation. Circulation Research. 2004; 94:208-14. PMid:14670844. http://dx.doi.org/10.1161/01. RES.0000111526.69133.DE

Dillon AR, Dell'Italia LJ, Tilson M, Killingsworth C, Denney T, Hathcock J, Botzman L. Left ventricular remodeling in preclinical experimental mitral regurgitation of dogs. Journal of Veterinary Cardiology. 2012; 14:73-82. PMid:22386719. http://dx.doi.org/10.1016/j.jvc.2012.01.012

Dosdall DJ, Fast DG, Ideker RE. Mechanisms of defibrillation. Annual Review of Biomedical Engineering. 2010; 12:233-58. PMid:20450352. http:// dx.doi.org/10.1146/annurev-bioeng-070909-105305

Fedorov VV, Nikolski VP, Efimov IR. Effect of electroporation on cardiac electrophysiology. In: Li S, editor. Electroporation Protocols: Preclinical and Clinical Gene Medicine. New York: Humana Press; 2008. p. 433-48. 
Fotuhi PC, Epstein AE, Ideker RE. Energy levels for defibrillation: what is of real clinical importance: American Journal of Cardiology. 1999; 83:24D-33D. http://dx.doi. org/10.1016/S0002-9149(98)00966-7

Gomes PAP, Bassani RA, Bassani JWM. Electric field stimulation of cardiac myocytes during postnatal development. IEEE Transactions on Biomedical Engineering. 2001; 48:630-6. PMid:11396593. http:// dx.doi.org/10.1109/10.923781

Gomes PA, De Galvão KM, Mateus EF. Excitability of isolated hearts from rats during postnatal development. Journal of Cardiovascular Electrophysiology. 2002; 13:355-60. PMid:12033352. http://dx.doi.org/10.1046/ j.1540-8167.2002.00355.x

Kaistura J, Zhang X, Liu Y, Szoke E, Chen W, Olivetti G, Hintze TH, Anversa P. The cellular basis of pacing-induced dilated cardiomyopathy: myocyte cell loss and myocyte cellular reactive hypertrophy. Circulation. 1995; 92:2306-17. PMid:7554216. http://dx.doi.org/10.1161/01.CIR.92.8.2306

Kalighi K, Daly B, Leino EV, Shorofsky SR, Kavesh NG, Peters RW, Gold MR. Clinical predictors of transvenous defibrillator energy requirement. American Journal of Cardiology. 1997; 79:150-3. http://dx.doi.org/10.1016/ S0002-9149(96)00702-3

Klee M, Plonsey R. Stimulation of spheroidal cells: the role of cell shape. IEEE Transactions on Biomedical Engineering. 1976; 23:347-54. PMid:1278928. http://dx.doi. org/10.1109/TBME.1976.324597

Kleinbaum DG. Survival Analysis: a Self-learning Text. New York: Springer-Verlag; 1996.

Knisley SB, Grant AO. Asymmetrical electrically induced injury of rabbit ventricular myocytes. Journal of Molecular and Cellular Cardiology. 1985; 27:1111-22. http://dx.doi. org/10.1016/0022-2828(95)90047-0

Knisley SB, Blitchington TF, Hill BC, Grant AO, Smith WM, Pilkington TC, Ideker R. Optical measurements of transmembrane potential changes during electrical field stimulation of ventricular cells. Circulation Research. 1993; 72:255-70. PMid:8418982. http://dx.doi. org/10.1161/01.RES.72.2.255

Krassowska W, Filev PD. Modeling electroporation in a single cell. Biophysical Journal. 2007; 92:404-17. PMid:17056739 PMCid:1751390. http://dx.doi.org/10.1529/ biophysj.106.094235

Mantel N. Evaluation of survival data and two new rank order statistics arising in its consideration. Cancer Chemotherapy Reports. 1966; 50:163-70. PMid:5910392.

Neunlist M, Tung L. Dose-dependent reduction of cardiac transmembrane potential by high intensity electrical shocks. American Journal of Physiology. 1997; 273:H2817-25. PMid:9435619.

Oliveira PX, Bassani RA, Bassani JWM. Cytosolic $\mathrm{Ca}^{2+}$ accumulation in ventricular myocytes after stimulation with high-intensity electric fields. Biophysical Journal. 2005; 88 (suppl. 1):1 (abstr. 1514).
Oliveira PX, Bassani RA, Bassani JWM. Lethal effect of electric fields on isolated ventricular myocytes. IEEE Transactions on Biomedical Engineering. 2008; 55:2635-42. PMid:18990634. http://dx.doi.org/10.1109/ TBME.2008.2001135

O’Neill RJ, Tung L. Cell-attached patch clamp study of the electropermeabilization of amphibian cardiac cells. Biophysical Journal. 1991; 59:1028-39. http://dx.doi. org/10.1016/S0006-3495(91)82318-9

Oshiyama NF, Bassani JWM, Bassani RA. Configuração do potencial de ação em miócitos ventriculares isolados de ratos neonatos e adultos. In: Proceedings of the I Simposio Brasileiro de Eletrofisiologia Celular; 2012; Belo Horizonte, MG. Belo Horizonte; 2012. p. 40 (abstr.).

Ott P, Reiter MJ. Effect of ventricular dilatation on defibrillation threshold in the isolated perfused rabbit heart. Journal of Cardiovascular Electrophysiology. 1997; 8:1013-9. PMid:9300299. http://dx.doi.org/10.1111/j.1540-8167.1997. tb00625.x

Penna LB, Bassani RA. Increased spontaneous activity and reduced inotropic response to catecholamines in ventricular myocytes from footshock-stressed rats. Stress. 2010; 13:73-82. PMid:19697264. http://dx.doi. org/10.3109/10253890902951778

Reinier K, Dervan C, Singh T, Uy-Evanado A, Lai S, Gunson K, Jui J, Chugh SS. Increased left ventricular mass and decreased left ventricular systolic function have independent pathways to ventricular arrhythmogenesis in coronary artery disease. Heart Rhythm. 2011; 8:1177-82. PMid:21376836 PMCid:3123721. http://dx.doi.org/10.1016/j. hrthm.2011.02.037

Ricardo RA, Oliveira PX, Bassani RA, Bassani JWM. Compact cell image projector: application to study the relationship between stimulus interval and contraction amplitude in isolated rat cardiomyocytes. Revista Brasileira de Engenharia Biomédica. 2006; 22:151-60.

Sharma V, Tung L. Spatial heterogeneity of transmembrane potential responses of single guinea-pig cardiac cells during electric field stimulation. Journal of Physiology. 2002; 542:477-92. PMid:12122146 PMCid:2290429. http://dx.doi.org/10.1113/ jphysiol.2001.013197

Sowell B, Fast VG. Ionic mechanism of shock-induced arrhythmias: role of intracellular calcium. Heart Rhythm. 2012; 9:96-104. PMid:21878203. http://dx.doi. org/10.1016/j.hrthm.2011.08.024

Tovar O, Tung L. Electroporation and recovery of cardiac cell membrane with rectangular voltage pulses. American Journal of Physiology. 1992; 263:H1128-36. PMid:1415761.

Tung L, Sliz N, Mulligan MR. Influence of electrical axis of stimulation on excitation of cardiac muscle cells. Circulation Research. 1991; 69:722-30. PMid:1873867. http://dx.doi. org/10.1161/01.RES.69.3.722

Valič B, Golzio M, Pavlin M, Schatz A, Faurie C, Gabriel B, Teissié J, Rols MP, Miklavčič D. Effect of electric field induced transmembrane potential on spheroidal cells: theory and experiment. European Biophysical Journal. 2003; 32:510-28. 
Virgen-Ortiz A, Marin JL, Elizalde A, Castro E, Stefani E, Toro L, Muñiz J. Passive mechanical properties of cardiac tissue in heart hypertrophy during pregnancy. Journal of Physiological Science. 2009; 59:391-6. PMid:19565322. http://dx.doi.org/10.1007/s12576-009-0047-5

Weaver JC, Chizmadzhev YA. Theory of electroporation: a review. Bioelectrochemistry and Bioenergetics. 1996; 41:135-60. http://dx.doi.org/10.1016/ S0302-4598(96)05062-3

Yabe S, Smith W, Daubert J, Wolf P, Rollins D, Ideker R. Conduction disturbances caused by high current density electric fields. Circulation Research. 1990; 66:1190-203. PMid:2335021. http://dx.doi.org/10.1161/01.RES.66.5.1190
Zipes DP, Camm AJ, Borggrefe M, Buxton AE, Chaitman B, Fromer M, Gregoratos G, Klein G, Moss AJ, Myerburg RJ, Priori SG, Quinones MA, Roden DM, Silka MJ, Tracy C. ACC/AHA/ESC 2006 guidelines for management of patients with ventricular arrhythmias and the prevention of sudden death - executive summary: a report of the American College of Cardiology/American Heart Association Task Force and the European Society of Cardiology Committee for Practice Guidelines (Writing Committee do Develop Guidelines for Management of Patients with Ventricular Arrhythmias and the Prevention of Sudden Cardiac Death). European Heart Journal. 2006; 27:2099-140. PMid:16923744. http://dx.doi. org/10.1093/eurheartj/ehl199

\footnotetext{
Authors

Jair Trapé Goulart

Department of Biomedical Engineering, School of Electrical and Computer Engineering - FEEC, University of Campinas - UNICAMP, Rua Alexander Fleming 163,

Cidade Universitária Zeferino Vaz, CEP 13083-881, Campinas, SP, Brasil.

Pedro Xavier de Oliveira, José Wilson Magalhães Bassani, Rosana Almada Bassani*

Department of Biomedical Engineering, School of Electrical and Computer Engineering - FEEC, University of Campinas - UNICAMP, Rua Alexander Fleming 163, Cidade Universitária Zeferino Vaz, CEP 13083-881, Campinas, SP, Brasil.

Center for Biomedical Engineering - CEB, University of Campinas - UNICAMP,

Rua Alexander Fleming 163, Cidade Universitária Zeferino Vaz, CEP 13083-881, Campinas, SP, Brasil.
} 